\title{
Pelvic osteosarcoma ressection in a bitch: case report
}

\author{
[Ressecção de osteossarcoma pélvico em cadela: relato de caso] \\ B.A. Rodrigues ${ }^{1}$, C. Faraco ${ }^{2}$, R. Oliveira ${ }^{1}$, S. Cheuiche $^{2}$, F.S. Teixeira ${ }^{2}$, \\ C. Kirst ${ }^{2}$, A. Faraon', E.M. Sousa ${ }^{3}$ \\ ${ }^{1}$ Faculdade de Medicina Veterinária - UFRGS \\ Av. Bento Gonçalves, 9090 \\ 91501-970 - Porto Alegre, RS \\ ${ }^{2}$ Hospital Veterinário - UFGRS - Porto Alegre, RS \\ ${ }^{3}$ Médico veterinário autônomo
}

\begin{abstract}
An osteosarcoma involving the pelvis was diagnosed in a 9-year-old neutered Labrador bitch. The clinical signs manifested by the patient before surgical removal of the tumor included urinary difficulty, dyschezia, and inconstant non-weight-bearing on the hindlimbs. These signs were linked to the localization of the tumor, which was identified as a firm and painful mass of the size of an orange in the caudal abdomen. The favorable short term clinical results after surgery and carboplatin chemotherapy showed that the association of these approaches can be employed to manage discomfort inflicted by tumor and, therefore improve the quality of life of patient of bone cancer.
\end{abstract}

Keywords: dog, osteosarcoma, chemotherapy, ultrasonography

\section{RESUMO}

Diagnosticou-se um osteossarcoma pélvico em uma cadela da raça Labrador de nove anos. Os sinais clínicos manifestados pela paciente antes da remoção do tumor incluiam dificuldade urinária, disquezia e dificuldade de sustentação do trem posterior. Estes sinais estavam associados à localização do tumor, identificado como uma massa firme e dolorosa do tamanho de uma laranja à região caudal do abdômen. Os resultados clínicos favoráveis observados em curto prazo depois da instauração de tratamento cirúrgico e quimioterápico com carboplatina mostram que a associação dessas condutas pode ser empregada para diminuir o desconforto imposto pelo tumor e, portanto melhorar a qualidade de vida em pacientes com câncer ósseo.

Palavras-chave: cão, osteossarcoma, quimioterapia, ultra-sonografia

\section{INTRODUCTION}

Cancer is the manifestation of uncontrolled cell growth and proliferation, and occurs as a result of genetic damage and/or changes in a cell (Modiano, 2005; Kenny et al., 2006). There are various types of cancer in pets, among them the bone tumors. Osteosarcoma is the most common bone tumor, accounting for over $95 \%$ of all bone tumors in dogs, and for $70 \%$ in cats (Bennet, 2004). Osteosarcoma has a predilection for long bone methaphyses (Jongeward, 1985). Axial bones such as head, ribs, and pelvis are affected in 25\% of cases (Brodey and Riser, 1969). Osteosarcoma accounts for only $4 \%$ of primary sacral tumors (Dahlin and Unni, 1986).

Diagnostic tests such as radiographs, bloodwork, and biopsy are required to determine the most appropriate treatment for cancer. Ultrasonography has been increasing potential value regarding examination of the musculoskeletal system of small animal (Kramer et al., 2004).

Recebido em 8 de fevereiro de 2008 
Advances in veterinary cancer are linked to the progress on knowledge of the mechanisms controlling the disease. Also, pain controll is one of the most important targets of cancer therapy. Dogs are quite variable in expressing discomfort, what implies in individual evaluation for optimal pain therapy. Analgesics such as non steroidal antinflammatory (NSAID) (e.g. carprofen, meloxican, and piroxican) and opioid (e.g. morphine, and fentanyl) are among the drugs used to prevent discomfort generated by cancer (Ogilvie and Moor, 2006).

Chemotherapy with carboplatin, which is a second-generation platinum compound can be employed to manage the progression of tumor, and has shown effective in extending survival time in dogs of osteosarcoma. In literature, outcome survival after chemotherapy is reported within 40 to $50 \%, 20$ to $30 \%$ at one and two years respectively. Only, 10 to $20 \%$ of cancer cases show durable long term remissions (Withrow, 2006). Medium survival life time after osteosarcoma diagnosis has been reported to be 120 days, with local recurrence being the most common cause of death (Hammer et al., 1995).

This report aimed to present the case of a pelvic osteosarcoma diagnosed in a Labrador bitch. The authors focused on the description of the physical signs exhibited by the patient before surgery, specify the tests used to establish the diagnosis, and comment the favorable short term recovery following tumor removal and carboplatin chemotherapy.

\section{CASUISTIC}

A 9-year-old neutered Labrador female was referred with a history of urinary difficulty and dyschezia associated with inconstant non-weightbearing on the hindlimbs. On physical examination, there was not evident etiology explaining the clinical condition. Results from a complete blood count and serum chemistry analysis, which included alanine transaminase (ALT) $(31.6 \mathrm{UI} / \mathrm{L})$ and creatinine $(0.6 \mathrm{mg} / \mathrm{dL})$, were within the normal limits of the species (Table 1). Urinanalysis showed the presence of rare hyalin cilindres and low level of bacteria. The female was premedicated with enrofloxacin (2.5mg/kg BID), meloxicam (0.1 mg/kg SID), and escopolamine (0.3mg SID). The animal response was poor, and 11 days later the patient was presented for clinical reevaluation. At recheck, physical examination revealed a firm and painful mass of the size of an orange in the caudal abdomen. Radiographic examination in the lateral aspect revealed discret periosteal reaction of pelvis and identified a mass localized proximal to the urinary blader (Fig. 1).

Ultrasonography confirmed the presence of a mass, which was classified as solid, according its texture and the view of an intensely hyperechoic acoustic shadow (Fig. 2, and 3). On the basis of physical, radiographic, and ultrasonographic findings, a presumptive diagnosis of neoplasm was established, and with the agreement of the owner, the female was submitted to an exploratory laparotomy.

Table 1. Bitch hematologic values by the time of first presentation

\begin{tabular}{ll}
\hline Erytrocytes $\left(\mathrm{x} 10^{6} / \mu \mathrm{L}\right)(5.5-8.5)$ & 6.04 \\
Hemoglobin $(\mathrm{Hgb})(\mathrm{gm} / \mathrm{dL})(12-18)$ & 15.2 \\
Hematocrit $(\mathrm{PCV})(\%)(37-55)$ & 43 \\
Mean corpuscular volume (MCV) (fl) (60-77) & 71.92 \\
Corpuscular hemoglobin concentration $(\mathrm{CHCM})(\%)(32-36)$ & 35.35 \\
Platelets $\left(\mathrm{x} 10^{3} / \mu \mathrm{L}\right)(200-500)$ & 68 \\
Total plasmatic protein $(\mathrm{gm} / \mathrm{L})(60-80)$ & 7400 \\
White blood cells (WBC) $(\mu \mathrm{L})(6000-17000)$ & 71 \\
Segmented neutrophils $(\%)(60-75)$ & 12 \\
Eosinophils (\%) (2-10) & 01 \\
Monocytes $(\%)(3-9)$ & 16 \\
Lymphocytes (\%) (12-30) & 16 \\
\hline
\end{tabular}

Perioperative therapy included ampicilin $(10 \mathrm{mg} / \mathrm{kg}, \mathrm{IV})$ and tramadol $(2 \mathrm{mg} / \mathrm{kg}, \mathrm{IM})$. At surgery, a $10 \mathrm{~cm}$ oval hemorragic structure was partially removed from a markedly thickened and irregular pelvis (Fig. 4). The mass had a mixed consistency, which varied from friable to solid, and was adhered to the pelvis. Macroscopically, there was no invasion of the mass to the adjacent organs. Postoperative therapy included enrofloxacin $\quad(5 \mathrm{mg} / \mathrm{kg} / \mathrm{IM}), \quad$ subcutaneous 
ketoprofen $(2 \mathrm{mg} / \mathrm{kg})$, and tramadol $(3 \mathrm{mg} / \mathrm{kg}$, IM).

The pathologist interpreted a tissue sample removed from the extirped structure as a fibroblastic osteosarcoma. The criterion used to confirm tumor diagnosis, in hematoxylin and eosin (H\&E) stained tissue sections was the detection of osteoid by tumor cells (Fig. 5, 6, and 7).

The dog was treated one day after surgery with oral ampicilin (10mg/kg, TID) and oral tramadol $(2 \mathrm{mg} / \mathrm{kg}, \mathrm{BID})$. Twenty-three days after surgery, platinum drug (carboplatin) chemotherapy was initiated. Chemotherapy protocol used carboplatin as single drug $\left(300 \mathrm{mg} / \mathrm{m}^{2}\right)$ in saline infusion $(250 \mathrm{~mL})$, and was performed on a 21 day-interval basis. Ampicilin and ondansetron $(0,1 \mathrm{mg} / \mathrm{kg}$, IV) were used for palliation of gastrointestinal disease and nausea. No side effects associated to carboplatin administration were observed. Metastasis of tumor to regional or distant organs was not detected by radiography. Unfortunatelly, four months after osteosarcoma removal, the bitch relapsed on its initial clinical condition, and under request of the owner, it was submitted to euthanasia.

\section{DISCUSSION AND CONCLUSION}

The number of dogs being diagnosed with cancer is remarkable. Cancer is, in essence, a genetic disease (Modiano, 2005). In the last decade, many important genes responsible for the genesis of various cancers have been discovered, their mutations precisely identified, and the pathways through which they act characterized (Vogelstein and Kinzler, 2004). Loss of function of tumor suppressor genes and gain of function of oncogenes appears to contribute to the origin of tumors (Modiano, 2005). Inactivation of the encoded nuclear phosphoprotein known as p53 tumor supressor gene has been implicated in the pathogenesis of human osteosarcomas (Johnson et al., 1998). The ecology of tumors as driven by chemical and physical forces exerted by the diverse cellular populations that surround a tumor (microenvironment) has been discussed in the literature (Kenny et al., 2006).

There are various types of cancer in pets, among them the bone tumors. Most primary bone tumors in dogs, particularly osteosarcomas, are malignant and arise spontaneously with unknown or apparent cause (Bennet, 2004; Liptak, 2006). They are highly aggressive neoplasms, characterized by local destruction and distant metastasis. Older dogs are most commonly affected by cancer (De Santis et al., 2007). However, bone tumors can occur in young dogs as well (Liptak, 2006). There is a biphasic prevalence age distribution curve for canine osteosarcoma, with peaks at two and seven years (Kuntz, 2001).

Osteosarcomas commonly affect the appendicular skeleton (humerus, femur, tibia, and radius/ulna). Other affected sites include the axial skeleton (skull, ribs, vertebrae, and pelvis), which is a more common primary site in smaller dogs. Nevertheless, it was recently observed that the frequency of primary osteosarcoma in bones of pelvis of Rottweiler and German Shepherd dogs may be expressive (Daleck et al., 2006). Interestingly, the pelvic osteosarcoma of the present case was observed in a Labrador bitch. The tumor caused difficulty in defecation and urination due to the pelvic occupation by the mass.

Cavalcanti et al. (2004) reported about the predominance of osteosarcoma among canine females. In spite of these findings, a male predisposition has been reported by other authors, and neutering or spaying, regardless of gender, may increase the risk of developing appendicular osteosarcoma (Ru et al., 1998).

Radiography, bloodwork, and biopsy are diagnostic tests required to determine the most appropriate treatment for cancer. Still, histopathology is the most reliable diagnostic method, and has been of value in determining prognostic information by tumor grading, tumor behavior at tissue level, and assessment of surgical ressection margins (Ehrhart, 2006). The histomorphology of osteosarcoma shows various appearences, which have in common the proliferation of malignant mesenchymal cells and the production of osteoid and/or bone by tumor cells. It is typically composed of spindle cells (Marina et al., 2004). Fibroblastic osteosarcoma, the tumor diagnosed in the female of this case report, was composed of malignant spindle-forming cells with a slight presence of osteoid (Unni, 1998; Marina et al., 2004). 


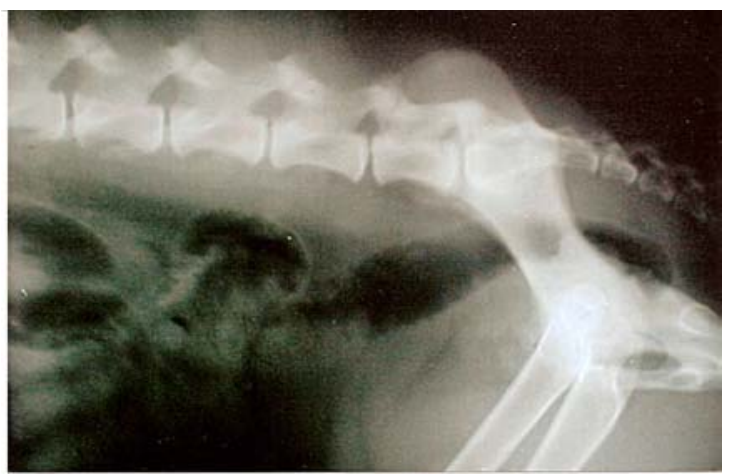

Figure 1. Bitch. Radiographic examination in the lateral aspect showing a discret periosteal reaction of pelvis and a mass localized proximal to the urinary bladder.

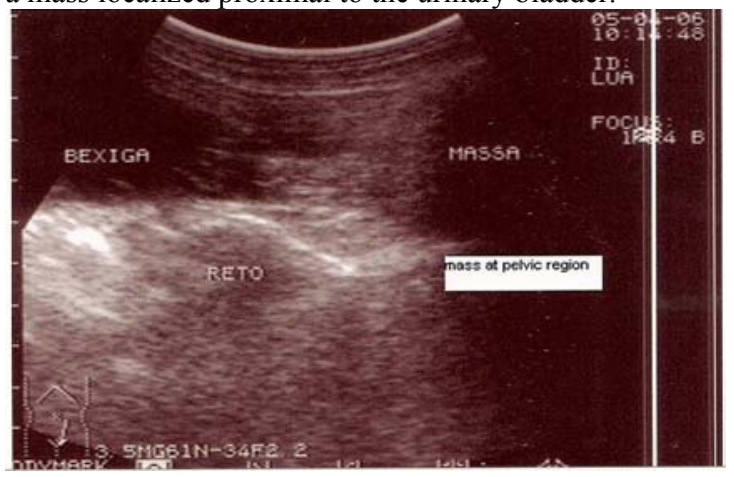

Figure 3. Bitch. Ultrasonographic view of a solid mass, rectum, and urinary bladder.

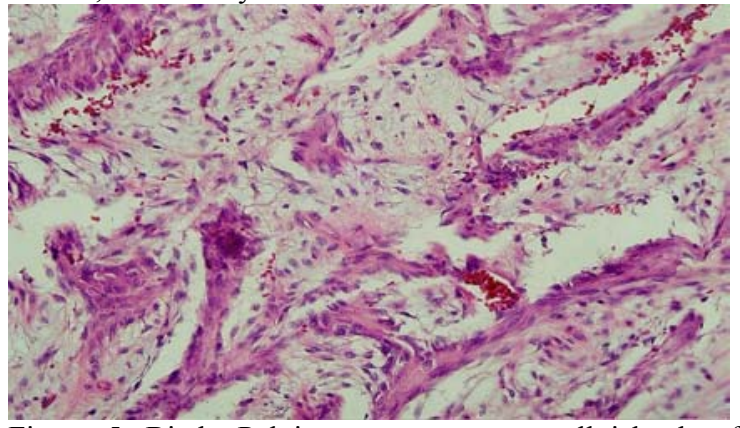

Figure 5. Bitch. Pelvic osteosarcoma: small islands of neoplastic osteoid matrix without mineralization arranged with scattered basophilic stroma (H\&E; original 20x).

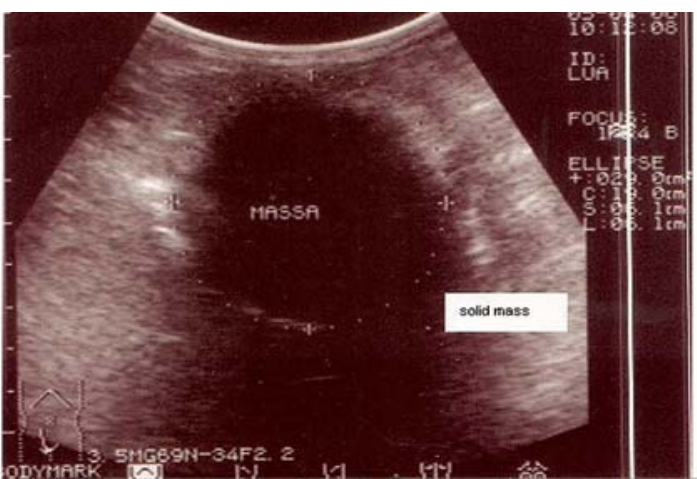

Figure 2. Bitch. Ultrasonographic size of a solid mass; view of circumference.

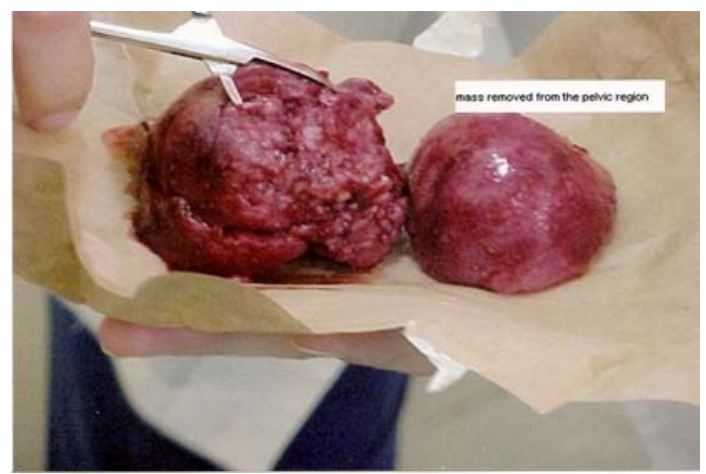

Figure 4. Bitch. Mass removed from the pelvic region.

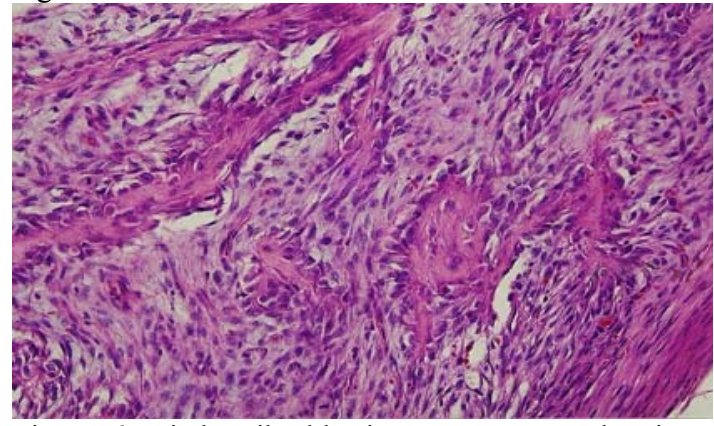

Figure 6. Bitch. Fibroblastic osteosarcoma showing irregular small islands of osteoid matrix without mineralization surrounded by malignant osteoblasts forming a fusiform pattern (H\&E; original 20x).

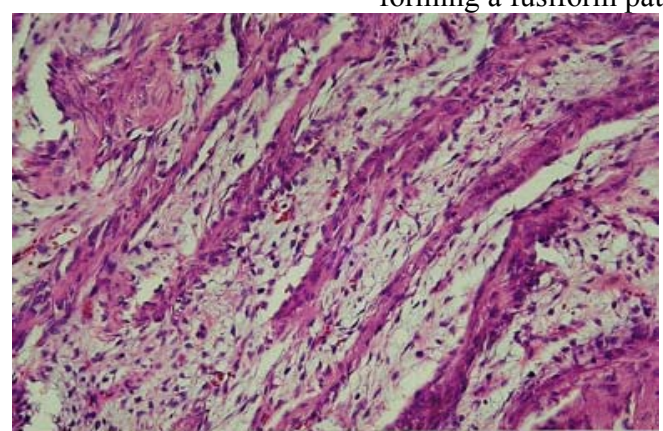

Figure 7. Bitch. Small islands of neoplastic osteoid matrix without mineralization arranged in parallel way with scattered stroma cells (H\&E; original 20x). 
In the present case, ultrasonographic examination was fundamental to diagnosis, whereas X-ray was unable to define with accuracy the presence and extent of tumor. Ultrasound image provided substantial information about the mass. Currently, masses are classified by their echotexture, and may have a variety of internal echoes, which may include shadowing, as it was observed in the present case.

Spread of tumor cells is rare in dogs with axial tumors, except for rib tumors and osteosarcoma of the scapula and pelvis (Liptak, 2006), the contrary of what was observed in the patient of the present report, in which no invasion of tumor cells to other organs could be observed by the time the manuscript was written. Metastasis evaluation in cancer patients is usually performed by radiography, because metastasis occurs primarily to the lungs and other bones, although a $25 \%$ rate of metastasis to regional lymphonodes is reported in the literature (Kirpensteijin et al., 2002). The presence of micrometastasis in more than $90 \%$ of dogs with osteosarcoma could be the reason for the undetectable metastasis in this clinical case.

Axial skeleton tumors do not rapidly grow as do appendicular tumors. Also, axial osteosarcomas follow a unique pattern and have a more insidious course of disease. Most owners seek veterinary attention only when clinical signs are exhibited by the animal. At this time, tumor spread and/or size may be interfering with the function of other organs, like in the present case, in which the major signs showed by the bitch at the time of first presentation were urinary difficulty and dyschezia.

Carboplatin was the drug chosen to treat the patient of this case report. Carboplatin administration was well tolerated by the patient. Adverse effects such as nephrotoxicity and emesis were not registered following chemotherapy. In fact, eighty percent of dogs complete the course of chemotherapy without any significant side effects. Only eighteen percent experience gastrointestinal complications (Kuntz, 2001).

Other modalities of osteosarcoma therapy are those with radiopharmaceutical bone targeting isotopes such as samarium -153-ethylenediamino-tetramethylene-phosphonate $\quad\left({ }^{153} \mathrm{Sm}\right.$ -
EDTMP) and the biologic treatment. Samarium allows the delivery of extremely high doses of local irradiation and provides pain relief, especially for dogs with primary osteoblastic lesions (Henry, 2006; Fan, 2006). The biologic treatment consists of approaches that alter the relationship among the tumor and the natural defense mechanisms of the host. The most promising agents are liposome-encapsulated muramyltripeptide, acemamman, interleukin-2, and monoclonal antibodies) (McEwen, 1993).

Radiograph studies have been mostly used in a serial manner to evaluate patient organic response under chemotherapy treatment. Other prognostic indicators for osteosarcoma include a list of variables among morphology, site of primary cancer, spread of tumor, grade and size of tumor, duration of symptoms, weight loss $<4.5 \mathrm{~kg}$, swelling of primary site, lytic appearence, and total and bone specific alkaline phosphatase (AP) levels (Taylor et al., 1989). As prognostic importance of AP levels before and after surgery have been controversial in the literature (Ehrhart et al., 1998; Bacon et al., 2006), this parameter was not taken into account in the present report. Unfortunatelly, other cancer prognostic indicators such as cyclooxygenase-2 (COX-2) expression, p-53, p-glyc, BMP, MVD, HER-2/neu, Met/HGF, and VEGF (Kramer et al., 2004; Withrow, 2006) are not currently available for veterinary use in Brazil.

In cancer patients, the severity and persistence of tumor, preexisting medical problems, and the dedication of the owner to agressive treatment influence disease progression. Despite the fact that, in the herein reported clinical case, the tumor was excised only partially due to its locally aderence to the pelvis, the patient experienced a survival life time of four months after cancer diagnosis establishment. The clinical favorable response herein described was comproved by patient regaining of a temporary physical good function outcome. Moreover, an acceptable quality of life of over 90 days was verified, according to medical and owner observations.

Early detection of osteosarcomas are paramount in determining treatment decisions. These measures contribute to a therapeutic plan and lead to rapid and positive responses before a clinical crisis hits. In the near future, investment 
in prevention of cancer will substantially limit the impact of the disease outbreak.

\section{ACKNOWLEDGMENT}

We gratefully acknowledge Prof. Dr. David Driemeier (Departamento de Patologia Faculdade de Medicina Veterinária - UFRGS) for generously providing the histology pictures.

\section{REFERENCES}

BACON, N.; EHRHART, N.; DERNELL, W. et al. Amputation plus alternating carboplatin and doxorrubicin chemotherapy for appendicular osteosarcoma in dogs. In: VETERINARY CANCER SOCIETY SYMPOSIUM ON CANINE OSTEOSARCOMA, 2006, Spring Valley. Proceedings ... Sedona: VCS, 2006. p.19.

BENNET, D. Feline bone diseases. In: EUROPEAN SOCIETY OF VETERINARY ORTHOPAEDICS AND TRAUMATOLOGY CONGRESS, 12., 2004, Munich, Proceedings... Munich, 2004. p.15.

BRODEY, R.S.; RISER, W.H. Canine osteosarcoma. Clin. Orthop. Relat. Res., v.62, p.54-64, 1969.

CAVALCANTI, J.N.; AMSTALDEN, E.M.I.; GUERRA, J.L. et al. Osteosarcoma in dogs: clinical-morphological study and prognostic correlation. Braz. J. Vet. Res. Anim. Sci., v.41, 2004.

DAHLIN, D.C.; UNNI, K.K. Osteosarcoma. In: DAHLIN, D.C.; UNNI, K.K. (Eds). Bone tumors. General aspects and data on 8542 cases. Springfield: Charles C. Thomas, 1986. p.269307.

DALECK, C.R.; CANOLA, J.C.; STEFANES, S.A. et al. Estudo retrospectivo de osteossarcoma primário dos ossos da pelve em cães em um período de 14 meses Braz. J. Vet. Res. Anim. Sci., v.43, p.125-131, 2006.

DE SANTIS, A.P.T.; OLIVEIRA VIANNA, G.N.; WERNER, P.R. Osteossarcoma em cães da raça Rottweiler: formas de apresentação clínico-patológicas. Disponível em: $<$ http://www.utp.br/medicinaveterinaria/jornadaa cademica/OSTEOSSARC_EM_CAES.pdf >. Acessado em 8 jan. 2007.
EHRHART, N.; DERNELL, W.S.; HOFFMANN, W.E. et al. Prognostic importance of alkaline phosphatase activity in serum from dogs with appendicular osteosarcoma: 75 cases (1990-1996). J. Am. Vet. Med. Assoc., v.213, p.1002-1006, 1998.

EHRHART, E.J. Current issues in the pathology of osteosarcoma. In: VETERINARY CANCER SOCIETY SYMPOSIUM ON CANINE OSTEOSARCOMA, 2006, Spring Valley. Proceedings... Sedona: VCS, 2006. p.48.

FAN, T.M. Therapeutic applications of aminobiphosphonates for treating canine osteosarcoma: present and future. In: VETERINARY CANCER SOCIETY (V.C.S.) SYMPOSIUM ON CANINE OSTEOSARCOMA, 2006, Spring Valley. Proceedings... Sedona: VCS, 2006. p.53-54.

HAMMER, A.S.; WEEREN, F.R.; WEISBRODE, S.E. et al. Prognostic factors in dogs with osteosarcomas of the flat or irregular bones. J. Am. Anim. Hosp. Assoc., v.31, p.321326, 1995.

HENRY, C.J. Radiopharmaceutical treatment of canine osteosarcoma. In: VETERINARY CANCER SOCIETY SYMPOSIUM ON CANINE OSTEOSARCOMA, 2006, Spring Valley. Proceedings... Sedona: VCS, 2006. p.5052.

JOHNSON, A.S.; COUTO, C.G.; WEGHORST, C.M. Mutation of the p53 tumor supressor gene in spontaneously ocurring osteosarcomas of the dog. Carcinogenesis, v.19, p.213-217, 1998.

JONGEWARD, S.J. Primary bone tumors. Vet. Clin. N. Am.: Small Anim. Pract. v.15, p.609641, 1985.

KENNY, P.A.; NELSON, C.M.; BISSEL, M.J. The ecology of tumors. Scientist, v.20, p.30-35, 2006.

KIRPENSTEIJIN, J.; KIK, M.; RUTTEMAN, G.R. et al. Prognostic significance of a new histologic grading system for canine osteosarcoma. Vet. Pathol., v.39, p.240-246, 2002.

KRAMER, M.; GERWING, M.; MICHELE, U. et al. What does ultrasound tell us about orthopedic problems. In: EUROPEAN SOCIETY Of VETERINARY ORTHOPAEDICS AND TRAUMATOLOGY CONGRESS, 12., 
2004, Munich, Proceedings... Munich, 2004. p.51-53.

KUNTZ, C.A. Canine osteosarcoma In: MALAWER, M.M., SUGARBAKER, P.H. (Eds). Musculoskeletal cancer surgery: treatment of sarcomas and allied diseases. Norwell: Kluwer Academic Publishers, 2001. p.601-606.

LIPTAK, J. Bone tumors in cat and dogs Disponível em: $<$ http://www.acvs.org/AnimalOwners/HealthCon ditions/index.cfm?ID=2783\&blnShowBack=Fals e\&idContentType $=939>$. Acessado em 21 jul. 2006.

MARINA, N.; GEBHARDT, M.; TEOT, L. et al. Biology and therapeutic advances for pediatric osteosarcoma. Oncologist, v.9, p.422-441, 2004.

McEWEN, E.G.; HELFAND, S.C. Recent advances in the biologic therapy of cancer. Compend. Cont. Educ.: Small Anim. Pract., v.15, p.909-916, 1993.

MODIANO, J.F. Genetics of canine cancer. In: TUFT'S CANINE AND FELINE BREEDING AND GENETICS CONFERENCE, 2005,
Sturbridge. Proceedings... Sturbridge, 2005. p.39.

RU, G.; TERRACINI, B.; GLICKMAN, L.T. Host related factors for canine osteosarcoma. Vet. J., v.156, p.31-39, 1998.

OGILVIE, G.K.; MOORE, A.S. Oncologic pain in dogs: prevention and treatment. Compend. Cont. Educ. Pract. Vet., v.28, p.776-785, 2006.

TAYLOR, W.F.; IVINS, J.C.; UNNI, K. et al. Canine mandibular osteosarcoma 51 cases (1980-1992). J. Am. Anim. Hosp. Assoc., v.32, p.257-262, 1989.

UNNI, K.K. Osteosarcoma of bone. J. Orthop. Sci., v.3, p.287-294, 1998.

VOGELSTEIN, B.; KINZLER, K.W. Cancer genes and the pathways they control. Nat. Med., v.10, p.789-799, 2004.

WITHROW, S.J. Reflections on progress in management of canine osteosarcoma. In: VETERINARY CANCER SOCIETY SYMPOSIUM ON CANINE OSTEOSARCOMA, 2006, Spring Valley. Proceedings... Sedona: VCS, 2006. p.46. 